WMD COMPLIANCE \& ENFORCEMENT SERIES

PAPER ONE
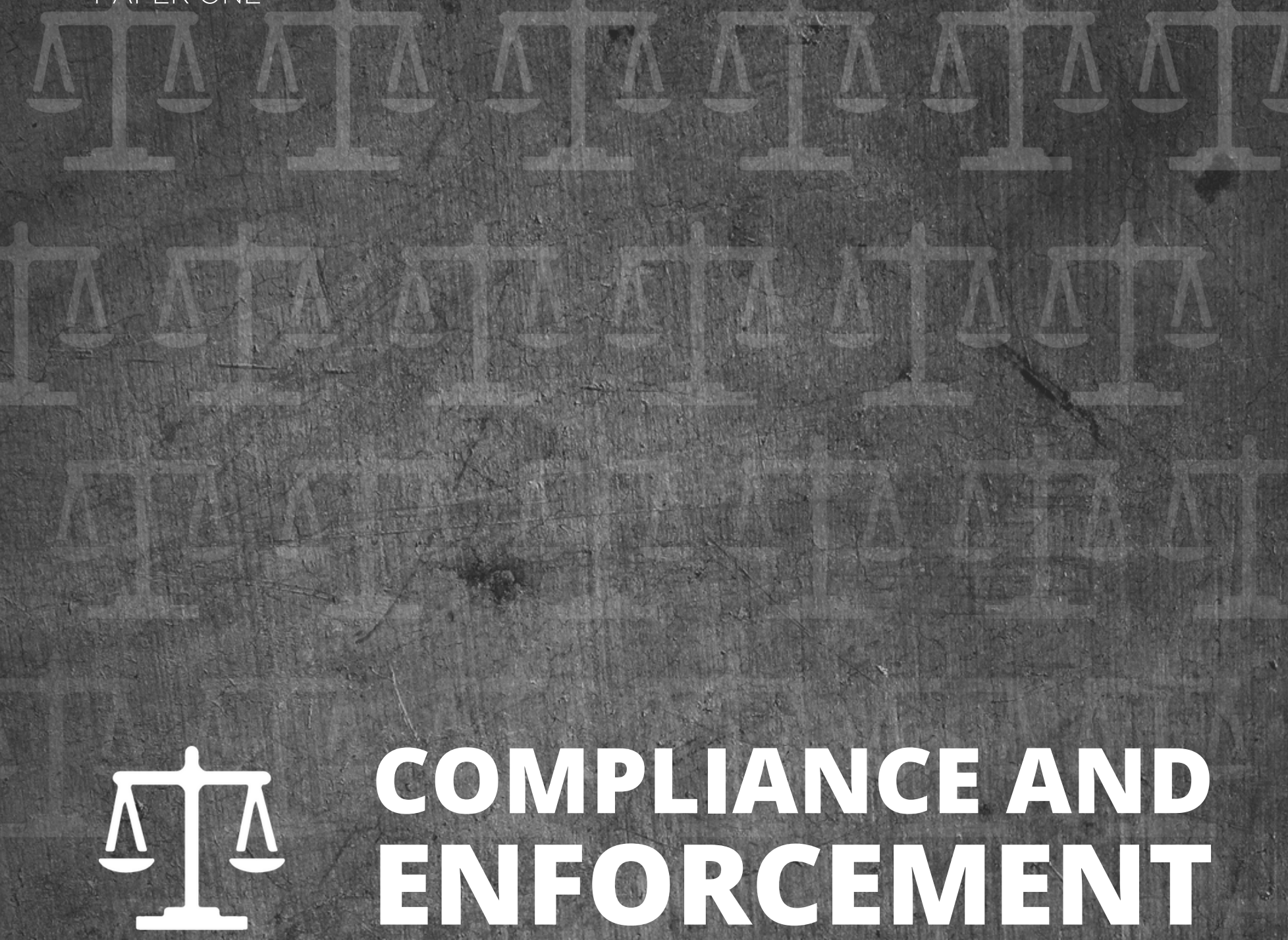

\title{
COMPLIANCE AND ENFORCEMENT IN WMD-RELATED TREATIES
}




\section{ACKNOWLEDGEMENTS}

Support from UNIDIR core funders provides the foundation for all of the Institute's activities. This project is supported by the Government of Norway.

\section{ABOUT UNIDIR}

UNIDIR is a voluntarily funded, autonomous institute within the United Nations. One of the few policy institutes worldwide focusing on disarmament, UNIDIR generates knowledge and promotes dialogue and action on disarmament and security. Based in Geneva, UNIDIR assists the international community to develop the practical, innovative ideas needed to find solutions to critical security problems.

\section{NOTE}

The designations employed and the presentation of the material in this publication do not imply the expression of any opinion whatsoever on the part of the Secretariat of the United Nations concerning the legal status of any country, territory, city or area, or of its authorities, or concerning the delimitation of its frontiers or boundaries. The views expressed in the publication are the sole responsibility of the individual authors. They do not necessary reflect the views or opinions of the United Nations, UNIDIR, its staff members or sponsors. 


\section{CONTENTS}

Summary.

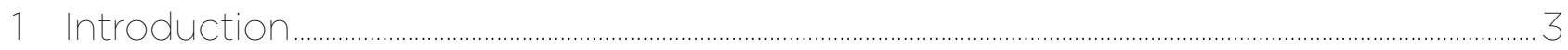

2 Compliance and enforcement in a nutshell........................................................................

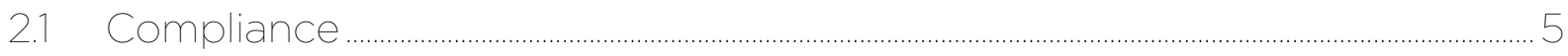

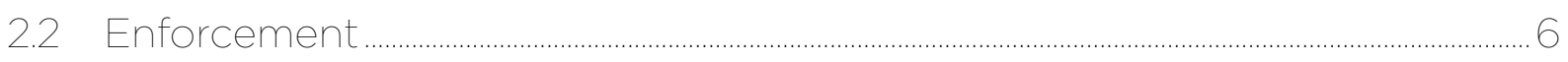

3 Treaty mechanisms for compliance and enforcement ......................................................... 7

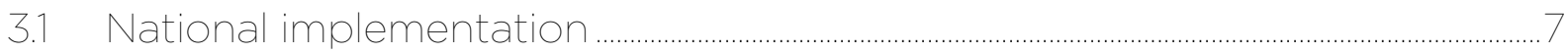

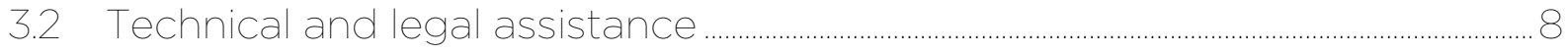

3.3 Transparency mechanisms, information-exchange and reporting ......................9

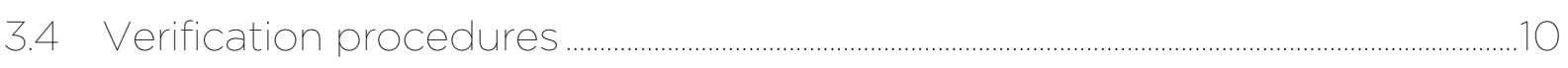

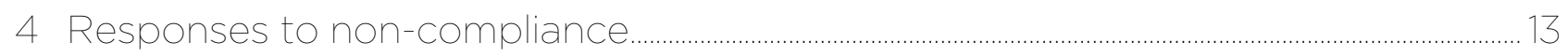

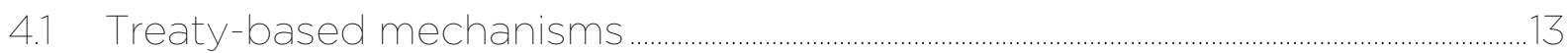

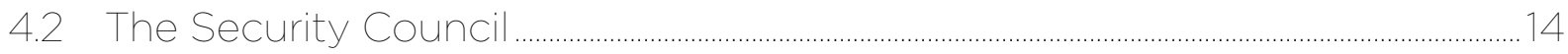

4.3 The International Court of Justice ...................................................................................... 14

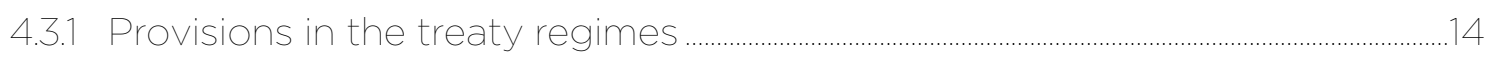

4.3.2 Routes to the ICJ outside treaty regimes..............................................................................15

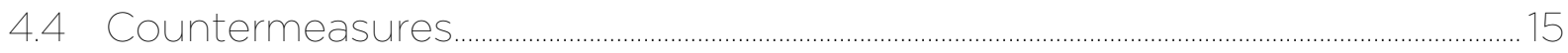

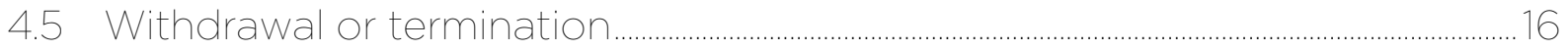

4.6 Other possible responses to non-compliance.......................................................17

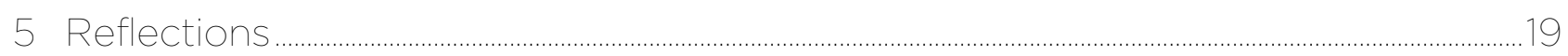




\section{ABOUT THE AUTHOR}

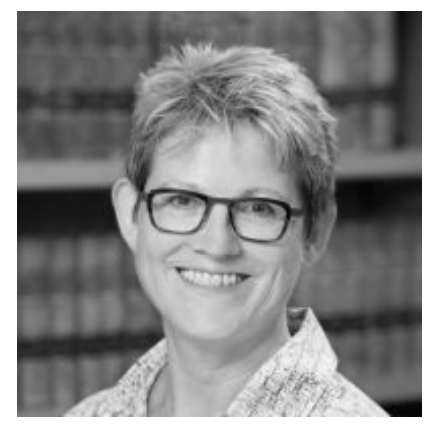

TREASA DUNWORTH is an Associate Professor at the Faculty of Law, University of Auckland, New Zealand. Dunworth's primary area of research is public international law, with an emphasis on the relationship between New Zealand law and international law, the law of international organizations and international security issues, particularly arms control and disarmament. In her work, reflecting her vision of the role of an academic, she engages with current developments as well as advance understanding of the issues in more reflective, critical work. Between 1995 and 1998, Dunworth worked with the Organization for the Prohibition of Chemical Weapons in The Hague. She has published on the way in which States translate their international arms control obligations into domestic law and on the accountability (or otherwise) of international agencies charged with advancing arms control and disarmament. Her book Understanding Humanitarian Disarmament will be published by Cambridge University Press in 2020. 


\section{ABBREVIATIONS AND ACRONYMS}

\begin{tabular}{ll} 
BWC & Biological Weapons Convention \\
\hline CBMs & Confidence-building measures \\
\hline CWC & Chemical Weapons Convention \\
\hline IAEA & International Atomic Energy Agency \\
\hline ICJ & International Court of Justice \\
\hline NPT & Treaty on the Non-Proliferation of Nuclear Weapons \\
\hline NTM & national technical means \\
\hline OPCW & Organisation for the Prohibition of Chemical Weapons \\
\hline WMD & weapons of mass destruction
\end{tabular}




\section{SUMMARY}

- This paper set out basic terms, concepts and understandings for exploring compliance and enforcement of WMD-related regimes, and the state of discussion about some relevant questions. The evolution of these regimes is incremental, with their respective development drawing on previous experiences in the same or similar fields. This reflects a degree of 'lock-in' to a particular understanding of compliance theory in arms control and disarmament. This leaves underexplored a rich range of tools, techniques and lessons from outside arms control and disarmament, for example in areas such as human rights or the environment.

- Compared with other issue areas, it is striking how little recourse there is to external methods of dispute resolution and enforcement. For example, there have been relatively few attempts to bring weapons-related disputes to the International Court of Justice. This in part no doubt reflects the difficulty of enforcing treaties in the sphere of WMD-related arms control and disarmament, but it also points to unused opportunities which might be available to develop new tools to resolve and enforce WMD-related treaties.

- The paper further points to the potential roles of different actors in feeding into WMD-related compliance and enforcement measures. States remain the primary actors in efforts towards compliance and enforcement. However, this should not discount greater potential role for other actors, including civil society, in enforcing and ensuring compliance. 


\section{INTRODUCTION}

A State meeting its obligations under a particular international treaty is said to be in compliance with that treaty. Enforcement can be understood as the actions which States Parties of a treaty-or at times, the international community more generally-might take in order to ensure compliance, or re-establish compliance, with the terms of the treaty. The two concepts are closely related, and at times overlap. For example, allowing international officials into a States' territory to inspect conditions in prisons, as required by an international treaty, might be seen as a State complying with its treaty obligation, but it can also be seen as the relevant international body enforcing the terms of the treaty. It is sufficient for the purposes of this paper to note the close relationship between compliance and enforcement and it can be helpful to think of them as operating on a continuum rather than as separate concepts. ${ }^{1}$

The aim of this paper is to explore questions that arise with compliance and enforcement in international law generally but also treaties related to weapons of mass destruction (WMD) specifically. To that end, part two explains in brief terms the concepts of 'compliance' and 'enforcement' and how they relate to each other. Part three then sets out the range of ways in which compliance and enforcement are addressed in international treaties, drawing on specific examples from WMD-related agreements. Part four examines possible responses to instances of non-compliance, which can be seen as the 'hard' end of enforcement. Part five concludes with some reflections on compliance and enforcement theory and practice in this area of international law.

\footnotetext{
${ }^{1}$ See for example Marauhn, Thilo, and Andreas Zimmermann. 2007. "Dispute Resolution, Compliance Control and Enforcement of International Arms Control Law". In Making Treaties Work: Human Rights, Environment and Arms Control, edited by Geir Ulfstein. pp. 243-72. https://doi.org/10.1017/CBO9780511494345.012. p. 243.
} 


\section{COMPLIANCE AND ENFORCEMENT IN A NUTSHELL}

\subsection{COMPLIANCE}

The ultimate goal of any treaty regime is that its States Parties comply with the obligations set out in the treaty. Compliance refers to both primary obligations-so first order treaty rules (for example, not to use chemical weapons as provided for in article 1 of the Chemical Weapons Convention (CWC)), ${ }^{2}$ as well as secondary obligations (for example, States must provide specified information to the CWC's implementing body within certain timeframes). Since the Second World War, it has become increasingly common in treaty-making generally for agreements to include mechanisms to induce compliance. ${ }^{3}$ Thus, increasingly, treaties in all areas of international law not only set out the respective rights and obligations of States Parties, but also provide fact-finding mechanisms, dispute resolution procedures and various enforcement mechanisms to ensure compliance with their terms. ${ }^{4}$

Understandings about why States comply (or do not) with their treaty obligations have evolved over time. ${ }^{5}$ Since at least the 1980s, two main strands of thought have provided competing explanations for treaty compliance. One group of explanations, termed the rational actor model, suggests that States will only comply with their international obligations when it is directly in their self-interest. In contrast, the so-called normative schools of thought suggest that compliance is best understood by examining the ways in which States perceive their long-term interests. These long-term interests might include a broad range of considerations, including reputation, a concern for the functioning of the international system, and an internalized commitment to international regimes on the part of State officials. ${ }^{6}$ More recent literature has explored compliance theory more thoroughly and new strands of thinking have been developed as a consequence that may have

${ }^{2}$ Convention on the Prohibition of the Development, Production, Stockpiling and Use of Chemical Weapons and on their Destruction, opened for signature 13 January 1993, 1975 UNTS 45 (entered into force 29 April 1997).

3 Ulfstein, Geir et al. 2007. "Introduction". In Making Treaties Work: Human Rights, Environment and Arms Control, edited by Geir Ulfstein. pp. 3-12. https://doi.org/10.1017/CBO9780511494345.002. Of course there are important exceptions to this general trend-the Biological Weapons Convention being a significant one in the context of weapons of mass destruction treaties, as discussed by Lentzos in paper four in this series. See Lentzos, Filippa. 2019. "Compliance and Enforcement in the Biological Weapons Regime" WMD Compliance and Enforcement series No. 4. UNIDIR.

${ }^{4}$ Chayes, Abram, and Antonia Handler Chayes. 1998. The New Sovereignty Compliance with International Regulatory Agreements.

${ }^{5}$ For discussions on definitions of 'compliance' see Stein, Jana Von. 2010. "International Law: Understanding Compliance and Enforcement". In The International Studies Encyclopedia, edited by Robert A. Denemark; Simmons, Beth A. 1998. "Compliance with International Agreements". Annual Review of Political Science 1: 75-93.

${ }^{6}$ Mitchell, Ronald B. 2008. "Compliance Theory: Compliance, Effectiveness, and Behaviour Change in International Environmental Law". In The Oxford Handbook of International Environmental Law, edited by Daniel Bodansky, Jutta Brunnée, and Ellen Hey. https://doi.org/10.1093/oxfordhb/9780199552153.013.0039. p. 894. 
implications for WMD-treaty compliance thinking. This is discussed more in section five and in Revill, Borrie, Podvig and Hart's cross-cutting paper in this series. ${ }^{7}$

Understanding why States comply with their obligations is essential in developing strategies for promoting compliance in any area of international law, including in designing regimes relating to WMD. For example, adopting a rational actor model would mean that sanctions for non-compliance and strong enforcement powers are essential to ensure compliance. On the other hand, a more normative approach would seek to encourage and facilitate compliance, rather than focus on punishments or threat of punishments for non-compliance.

\subsection{ENFORCEMENT}

Enforcement can be understood as actions to induce, or force, compliance with treaty obligations. Enforcement can range from 'soft', positive inducement measures, such as providing technical or legal assistance to States working towards compliance, through to 'hard' inducement measures, such as public naming and shaming, the suspension of privileges, and the imposition of sanctions.

Seeing enforcement measures along a spectrum from 'soft' to 'hard' in this way reveals the overlap between soft compliance measures and harder enforcement measures. It can therefore be more helpful to think of these concepts as running along a continuum, rather than existing as entirely separate categories.

\footnotetext{
${ }^{7}$ Revill, James, John Borrie, Pavel Podvig and Jenn Hart. 2019. "Compliance and Enforcement: Lessons from across WMD Related-Regimes". WMD Compliance and Enforcement series No. 6. UNIDIR.
} 


\section{TREATY MECHANISMS FOR COMPLIANCE AND ENFORCEMENT}

Unlike in domestic legal orders, there is no over-arching supreme decisionmaking/enforcement body in the international system, with the authority to impose sanctions for non-compliance. States are free to devise different mechanisms for each treaty regime, although those regimes do sit within the corpus of general international law, and they must comply with that body of law. For example, a treaty's enforcement provisions would need to comply with the general international law rules on prohibitions on the use of force. ${ }^{8}$ This part looks more closely at the way in which different treaty regimes approach the question of compliance and enforcement.

\subsection{NATIONAL IMPLEMENTATION}

An essential component of WMD-related treaties is national implementation. Many of the obligations undertaken in a treaty will have an impact in the domestic legal sphere, rather than internationally. For example, as discussed further by Lentzos in this paper series, the Biological Weapons Convention (BWC) requires States Parties to take "any necessary measures" to ensure compliance with the central obligations under the treaty. ${ }^{9}$ This might entail both legislative and administrative changes in the domestic sphere, but could also include wide range of other activities. Similarly, the CWC, as covered by Trapp, has a number of provisions related to national implementation. ${ }^{10}$ Most important is that States Parties enact penal legislation to proscribe at the national level those activities prohibited under the CWC. ${ }^{11}$ In other words, the development, production, acquisition, stockpiling, retention, transfer or use of chemical weapons must be prohibited as a matter of domestic law, affecting individuals within that legal space. In this way, domestic legislation becomes a

\footnotetext{
${ }^{8}$ See art. 2(4) (prohibition on the use of force) and art. 103 (providing that the obligations in the Charter of the United Nations prevail over other treaty obligations of States Parties) of the Charter of the United Nations.

${ }^{9}$ Convention on the Prohibition of the Development, Production and Stockpiling of Bacteriological (Biological) and Toxin Weapons and on their Destruction, opened for signature 10 April 1972, 1015 UNTS 163 (entered into force 26 March 1975). art IV. For discussion, see Dunworth, Treasa, Robert Mathews, and Timothy McCormack. 2006. "National Implementation of the Biological Weapons Convention". Journal of Conflict and Security Law 11 (1): 93-118. See also Lentzos, Filippa. 2019. "Compliance and Enforcement in the Biological Weapons Regime" WMD Compliance and Enforcement series No. 4. UNIDIR.

10 Trapp, Ralf. 2019. "Compliance Management under the Chemical Weapons Convention." WMD Compliance and Enforcement series No. 3. UNIDIR.

11 Tabassi, Lisa, Thilo Marauhn, and Andreas Zimmermann. 2007. "The Convention on the Prohibition of the Development, Production, Stockpiling and Use of Chemical Weapons and on Their Destruction (Chemical Weapons Convention)". In Making Treaties Work: Human Rights, Environment and Arms Control, edited by Geir Ulfstein. pp. 273-300. https://doi.org/10.1017/CBO9780511494345.013. p. 291.
} 
compliance tool for the treaty itself and provides a division of labour between the national agencies and the international implementing body. ${ }^{12}$

\subsection{TECHNICAL AND LEGAL ASSISTANCE}

Another important compliance process comes in the form of providing States Parties assistance in ensuring that they are in compliance with their own obligations. This might be delivered in the form of technical assistance (e.g. training of officials), or legal assistance (e.g. drafting domestic legislation). Assistance might also relate to the primary obligations undertaken in the treaty. For example, States may require help in fulfilling an obligation to destroy existing weapons stockpiles. Such assistance might be provided on a bilateral basis between States, or institutionalized through an international body, such as the Organisation for the Prohibition of Chemical Weapons (OPCW), the CWC's implementing organization. ${ }^{13}$ Treaties will often allow for, and indeed encourage, States Parties and where appropriate other entities to offer assistance to other States Parties. However, there is not necessarily always an obligation to offer or receive that assistance. This might suggest that these programmes should not be seen as an 'enforcement' measure. However, despite its voluntary nature, the provision of assistance by States Parties to other States Parties does fall within a broad understanding of 'compliance' as it is an important practical means of encouraging and supporting States to fully comply with their treaty obligations.

Technical and legal assistance is an important part of treaty compliance and enforcement for two key reasons. First, as treaties have become increasingly detailed and demanding, the obligation to undertake national implementation has become more complex, timeconsuming and expensive. ${ }^{14}$ There is therefore a need for technical and legal assistance.

The second reason is that the vast majority of States do not pose a security risk to these treaties and do not have-and have not had-stockpiles of the weapons in question. For example, Treaty on the Non-Proliferation of Nuclear Weapons (NPT) States may have become party to the treaty for reasons which are nothing to do with nuclear weapons. ${ }^{15}$ Rather, they may variously have sought to be seen as a 'responsible' international citizen; have wanted to secure the promise of enhanced cooperation in trade or technical expertise; had a genuine commitment to international peace and security and perhaps even demilitarization; or have wanted to ensure continued trading access to particular

\footnotetext{
${ }^{12}$ See for example the requirement for National Authorities under the CWC as discussed by Robinson, Julian Perry. 2008. "Is the OPCW Implementing the CWC Definition of Chemical Weapons?" The CBW Conventions Bulletin February (78): $1-2$.

${ }^{13}$ Not to be confused with provisions in treaties that have international cooperation and assistance provisions such as art. $\mathrm{X}$ of the BWC, art. XI of the CWC and art. IV of the NPT, which are designed as inducements to participation, rather than mechanisms to support compliance. In addition, Security Council resolution 1540 (2004) has invited States to provide implementation assistance. See also resolution 1810 (2008) and resolution 2325 (2016).

${ }^{14}$ For a discussion in the context of the CWC, see Mathews, Robert J., and Timothy L.H. McCormack. 1995. "Entry into Force of the Chemical Weapons Convention: National Requirements and Prospective Timetable". Security Dialogue 26 (1): 93-107.

15 The Treaty on the Non-Proliferation of Nuclear Weapons opened for signature 1 July 1968, 729 UNTS 161 (entered into force 5 March 1970).
} 
technologies. In these situations, the provision of assistance in national implementation activities related to the treaty in question is an effective way of ensuring strong domestic measures to implement the treaty (which in turn strengthens compliance) while not overburdening the States in question.

\subsection{TRANSPARENCY MECHANISMS, INFORMATION-EXCHANGE AND REPORTING}

Transparency mechanisms, including exchanging information and systems of reporting, constitute a third important process in compliance and enforcement procedures in WMDrelated treaty regimes. Transparency among States Parties can build trust within the treaty regime, avoid the risk of misperceptions, and therefore promote compliance and strengthen the underlying norm. ${ }^{16}$ Even when transparency is insufficient to build trust and strengthen the underlying norm, there is no doubt that contemporary WMD-related treaty practice has advanced to the point where it is difficult to imagine that States would agree to commit to treaty obligations without some form of transparency mechanism in place as regards the practice of other States Parties.

Over time, transparency mechanisms have increased in WMD-related treaty regimes. Early weapons-related treaties did not address transparency at all. ${ }^{17}$ However, in the post-Second World War period, declarations and confidence-building measures (CBMs) by States emerged as important transparency mechanisms. ${ }^{18}$ It is now commonplace that this kind of information-sharing takes place through organizations such as the the International Atomic Energy Agency (IAEA) or the OPCW.

Although there are exceptions where information through CBMs has been publicized to build confidence, ${ }^{19}$ generally the information provided in declarations is closely guarded and kept confidential among States Parties of the treaty. ${ }^{20}$ In contrast, the practice in recent nonWMD arms control treaties has been more open in terms of declarations. Thus, in the context of the 1997 Anti-Personnel Mine Ban Convention ${ }^{21}$ and the 2008 Convention on Cluster

\footnotetext{
${ }^{16}$ Marauhn, Thilo, and Andreas Zimmermann. 2007. "Dispute Resolution, Compliance Control and Enforcement of International Arms Control Law". In Making Treaties Work: Human Rights, Environment and Arms Control, edited by Geir Ulfstein. pp. 243-72. https://doi.org/10.1017/CBO9780511494345.012. But, for an argument that transparency does not always have benign effects, Allison and Carson suggest that disclosures about non-compliance might weaken the rules and that under some conditions, shining a light on non-compliance can stress and weaken a regime; see Carnegie, Allison, and Austin Carson. 2018. "The Spotlight's Harsh Glare: Rethinking Publicity and International Order". International Organization 72 (3): 627-57. https://doi.org/10.1017/S0020818318000176. p. 629.

17 See for example the Protocol for the Prohibition of the Use in War of Asphyxiating, Poisonous or Other Gases, and of Bacteriological Methods of Warfare, opened for signature 17 June 1925 (1929) XCIV LNTS 65-74 (entered into force 8 February 1928).

${ }^{18}$ See for example the Biological Weapons Convention CBMs or the bilateral agreements between the United States and the Soviet Union.

${ }^{19}$ See for example the published BWC CBMs available from the BWC website at https://bwc-ecbm.unog.ch/.

${ }^{20}$ See for example para. 2(c)(ii) of the Annex on the Protection of Confidential Information of the Chemical Weapons Convention.

${ }^{21}$ Convention on the Prohibition of the Use, Stockpiling, Production and Transfer of Anti-Personnel Mines and on their Destruction, opened for signature 3 December 1997, 2056 UNTS 211 (entered into force 1 March 1999).
} 
Munitions, ${ }^{22}$ information provided by States on their compliance activities is made publicly available. $^{23}$

Practice in human rights law goes even further. Transparency through State declarations has long been an important feature of international human rights law. This typically took the form of State reports to various treaty bodies. Over time, that practice has evolved to include standardized formats that are accompanied by so-called 'shadow reports' prepared by civil society and presented to the relevant treaty bodies. This example shows that other, more rigorous forms of transparency are possible. ${ }^{24}$ Moreover, it suggests that there is a role for a range of actors in building transparency. As Marauhn points out however, reporting systems can be hugely time-consuming and problematic. ${ }^{25}$

\subsection{VERIFICATION PROCEDURES}

Moreover, a robust compliance and enforcement mechanism needs more than transparency. There is also a need for fact-checking. In the context of arms control, such fact-checking takes place through verification procedures. ${ }^{26}$ While early arms control treaty regimes did not contain verification procedures, today they are considered essential components of any robust treaty regime.

An early form of verification was through so-called 'national technical means' (NTM). NTM includes such technologies as satellites, radar as well as other forms of intelligence gathering to conduct unilateral observations to ensure that other Parties of a treaty are in compliance. ${ }^{27}$ The 1992 Open Skies Treaty serves as one example. It allows for unarmed aerial observation flights over the territories of its States Parties. ${ }^{28}$ New START, as discussed by Podvig and Woolf in paper five of this series, provides a further example of how NTM have been applied in bilateral treaties. ${ }^{29}$ Such capabilities can be useful in building compliance systems.

${ }^{22}$ Convention on Cluster Munitions, opened for signature 3 December 2008, 2688 UNTS 39 (entered into force 1 August 2010).

${ }^{23}$ First Meeting of the States Parties to the APLM Convention, Final Report (APLC/MSP.1/1999/1, 20 May 1999), Annex III ("Circulation of Article 7 Reports"). Interestingly, this approach (making the declarations publicly available) had been rejected during the negotiations for the treaty.

${ }^{24}$ But there is a vigorous debate as to the value of those procedures; see for example Carnegie, Allison, and Austin Carson. 2018. "The Spotlight's Harsh Glare: Rethinking Publicity and International Order". International Organization 72 (3): 627-57. https://doi.org/10.1017/S0020818318000176.

${ }^{25}$ Marauhn, Thilo, and Andreas Zimmermann. 2007. "Dispute Resolution, Compliance Control and Enforcement of International Arms Control Law". In Making Treaties Work: Human Rights, Environment and Arms Control, edited by Geir Ulfstein. pp. 243-72. https://doi.org/10.1017/CBO9780511494345.012. p. 260.

${ }^{26}$ Ibid. p. 258.

27 Ibid.

${ }^{28}$ Treaty on Open Skies, Helsinki, 24 March 1992. Discussed by Marauhn, Thilo, and Andreas Zimmermann. 2007. "Dispute Resolution, Compliance Control and Enforcement of International Arms Control Law". In Making Treaties Work: Human Rights, Environment and Arms Control, edited by Geir Ulfstein. pp. 243-72. https://doi.org/10.1017/CBO9780511494345.012. p. 259. See also Poucet, André. 2006. "Arms Control and NonProliferation Treaties: An Ontology of Concepts and Characteristics". In Verifying Treaty Compliance, edited by Avenhaus, R., N. Kyriakopoulos, M. Richard and G. Stein. pp. 41-60. https://doi.org/10.1007/3-540-33854-3 3 . p. 45.

${ }^{29}$ Podvig, Pavel and Amy Woolf. 2019. "Monitoring, verification, and compliance resolution in U.S.-Russian arms control." WMD Compliance and Enforcement series No. 5. UNIDIR. 
However, NTM often require considerable resources to develop and maintain. ${ }^{30}$ As discussed further by Revill, Borrie, Podvig and Hart in this series, the results of NTM can be politicized.

Observation can also take place multilaterally, through an international body. The International Monitoring System designed within the Comprehensive Test Ban Treaty ${ }^{31}$ serves as an example. It has established a network of technological systems designed to detect nuclear explosions around the globe by detecting vibrations, as well as radionuclides, in the atmosphere. ${ }^{32}$

In-country, on-site inspections are now a common verification tool in contemporary treaties. ${ }^{33}$ There are important differences between the various regimes, both as to the techniques available but also the degree of intrusiveness involved. Some, such as the CWC regime and the IAEA Safeguards system, as discussed by Heinonen and Trapp in papers two and three respectively, have highly institutionalized processes, with international agencies conducting visits and inspections and reporting back to political bodies. ${ }^{34}$ Inspections range from routine procedures which are seen as CBMs, to challenge inspections which arise from a direct allegation made by one or more of the States Parties against another State Party. ${ }^{35}$ An investigation of alleged use of chemical or biological weapons can also be undertaken through the OPCW or the Secretary-General's Mechanism for Investigation of Alleged Use of Chemical and Biological Weapons. ${ }^{36}$

${ }^{30}$ Moodie, Michael, and Amy Sands. 2001. "New Approaches to Compliance with Arms Control and Nonproliferation Agreements". The Nonproliferation Review 8(1). pp. 1-9.

${ }^{31}$ Comprehensive Nuclear-Test-Ban Treaty, opened for signature 24 September 1996, 35 ILM 1439 (not yet in force).

32 Poucet, André. 2006. "Arms Control and Non-Proliferation Treaties: An Ontology of Concepts and Characteristics". In Verifying Treaty Compliance, edited by Avenhaus, R., N. Kyriakopoulos, M. Richard and G. Stein. pp. 41-60. https://doi.org/10.1007/3-540-33854-3 3. p. 44. See also Tabassi, Lisa, Thilo Marauhn, and Andreas Zimmermann. 2007. "The Convention on the Prohibition of the Development, Production, Stockpiling and Use of Chemical Weapons and on Their Destruction (Chemical Weapons Convention)". In Making Treaties Work: Human Rights, Environment and Arms Control, edited by Geir Ulfstein. pp. 273-300. https://doi.org/10.1017/CBO9780511494345.013. p. 299.

${ }^{33}$ For an overview see: Poucet, André. 2006. "Arms Control and Non-Proliferation Treaties: An Ontology of Concepts and Characteristics". In Verifying Treaty Compliance, edited by Avenhaus, R., N. Kyriakopoulos, M. Richard and G. Stein. pp. 41-60. https://doi.org/10.1007/3-540-33854-3 3. pp. 42-46.

34 See Heinonen, Olli. 2019. "The IAEA Mechanisms to Ensure Compliance with NPT Safeguards." WMD Compliance and Enforcement series No. 2. UNIDIR; Trapp, Ralf. 2019. "Compliance Management under the Chemical Weapons Convention." WMD Compliance and Enforcement series No. 3. UNIDIR.

${ }^{35}$ See for example, CWC, art. XII, Intermediate-Range Nuclear Forces Treaty and the Treaty on Conventional Armed Forces in Europe. For an analysis of the challenge inspection regime, see Abe, Tatsuya. 2017. "Challenge Inspections under the Chemical Weapons Convention: Between Ideal and Reality". Nonproliferation Review 24 (1-2): 167-84. https://doi.org/10.1080/10736700.2017.1380429.

${ }^{36}$ See for example, art. IX(8), CWC or the role of the Secretary-General's Mechanism. For further information on the latter, see the UNODA webpage on Secretary-General's Mechanism for Investigation of Alleged Use of Chemical and Biological Weapons: https://www.un.org/disarmament/wmd/secretary-general-mechanism/ 


\section{RESPONSES TO NON-COMPLIANCE}

The foregoing section has provided an overview of ways in which treaties might encourage compliance by States Parties and provide systems so that each State's compliance can be monitored by the other States Parties, whether that happens bilaterally, multilaterally or through an international agency. Contemporary treaties will also generally provide measures which can be taken within the treaty regime to redress situations of non-compliance and enforce the obligations under a treaty.

\subsection{TREATY-BASED MECHANISMS}

The first logical enforcement step in the face of concerns about non-compliance is to institute some form of dispute resolution procedures within the treaty regime itself. Most WMD-related treaties include provisions on dispute resolution generally, as well as specific measures to address disputes arising out of concerns over non-compliance. These will generally start from 'soft form' enforcement measures to encourage compliance and include, for example, processes and timelines for consultations, fact-finding mechanisms and cooperation among the Parties of the treaty. ${ }^{37}$

From there, and depending on the outcome of any fact-finding mechanisms, some treaties may provide more severe options, such as imposing sanctions on an errant State Party, or withdrawing privileges otherwise available under the treaty. Sanctions include such actions as trade embargoes, and arms embargos designed to bring an errant State back into compliance. ${ }^{38}$ Sanctions are therefore particularly important as a means of inducing compliance or changing non-compliant behaviour.

Generally, the dispute resolution provisions in treaty regimes are designed to gradually escalate in intensity. This serves as a form of compliance 'ladder'. ${ }^{39}$ This is consistent with the overall aim of trying to ensure compliance within the treaty community, prevent escalation of disputes and defuse problematic situations. ${ }^{40}$ However, such a progressive approach relies on a formal institutionalized framework and political support for resolving or addressing the dispute, so that momentum can be maintained in working through the requisite steps to

\footnotetext{
${ }^{37}$ See for example, art. IX, CWC; 1996 Comprehensive Nuclear-Test-Ban treaty, art. IV; 1977 Environmental Modification Convention, art. V; 1997 Anti-Personnel Mines Treaty, art. 8; 1981 Convention on Certain Conventional Weapons, Compliance Mechanism; 1999 and 2011 Vienna CSBM Document, chp. III; and 2000 Cartagena Protocol on Biosafety, Compliance Committee.

${ }^{38}$ But some commentators argue that there is considerable evidence to suggest that sanctions end up being counterproductive. The examples of Iraq, the Islamic Republic of Iran and the Democratic People's Republic of Korea would seem to illustrate the point.

${ }^{39}$ Thanks to Pavel Podvig for pointing the author to this useful term.

${ }^{40}$ Kenyon, lan R., and Treasa Dunworth. 1997. "Conflict Management and the Chemical Weapons Convention". Leiden Journal of International Law 10 (1): 81-90. https://doi.org/10.1017/S092215659700006X.; Marauhn, Thilo, and Andreas Zimmermann. 2007. "Dispute Resolution, Compliance Control and Enforcement of International Arms Control Law". In Making Treaties Work: Human Rights, Environment and Arms Control, edited by Geir Ulfstein. pp. 243-72. https://doi.org/10.1017/CBO9780511494345.012. p. 267.
} 
resolve the disagreement. Even then, depending on membership and decision-making rules, it can be difficult to entirely resolve a dispute, rather than simply manage it and prevent it from escalating.

\subsection{THE SECURITY COUNCIL}

Many cases of persistent non-compliance with WMD-related treaties have fallen within the mandate of the Security Council with its power to exercise authority over all matters of international peace and security. Thus, even in the absence of a specific reference in any given treaty regime, the Security Council would likely have authority to act if non-compliance is considered to reach the level of threatening international peace and security. In any event, many treaties make specific reference to the role of the Security Council. For example, article $\mathrm{VI}$ of the BWC provides that any State Party of the treaty can lodge a complaint with the Security Council regarding non-compliance.

\subsection{THE INTERNATIONAL COURT OF JUSTICE}

There is no centralized, automatic recourse to judicial forms of dispute resolution in international law generally or in the area of arms control and disarmament specifically. However, there are examples of attempts by States to enforce compliance of WMD-treaties through the International Court of Justice (ICJ).

\subsubsection{Provisions in the treaty regimes}

Some weapons-related treaties specifically provide for a referral of a dispute regarding compliance to the ICJ. ${ }^{41}$ However, these provisions are generally very constrained, most likely because negotiating States preferred to keep a dispute within the treaty regime rather than it being externally and independently adjudicated upon. ${ }^{42}$ For example, as discussed in more depth by Trapp, in the CWC, the resort to the ICJ by States is found, not in the provision relating to non-compliance (art. XII) but instead in the general dispute resolution provision, article XIV ${ }^{43}$ There it provides that a dispute relating to the "interpretation or application" of the treaty can be referred to the ICJ but only "by mutual consent", which likely renders the provision redundant. Unsurprisingly then, this course of action has never been pursued by any State Party of the treaty.

In addition to this provision, both the Conference of the States Parties (the membership organ of the OPCW) and the Executive Council (the executive body) are empowered to

\footnotetext{
${ }^{41}$ See for example, art. 17(2), Convention on the Physical Protection of Nuclear Material and Treaty of Pelindaba, which allows referral to the ICJ for disputes relating to the interpretation of the treaty; see discussion in Fry, James D. 2008. "Arbitrating Arms Control Disputes". Stanford Journal of International Law, Summer: 359.

42 See Kenyon, lan R., and Treasa Dunworth. 1997. "Conflict Management and the Chemical Weapons Convention". Leiden Journal of International Law 10 (1): 81-90. https://doi.org/10.1017/S092215659700006X; see also the discussion by James Fry on provisions relating to arbitration (also referring to the ICJ) in arms control treaties; Fry, James D. 2008. "Arbitrating Arms Control Disputes". Stanford Journal of International Law, Summer: 359.

43 Trapp, Ralf. 2019. "Compliance Management under the Chemical Weapons Convention." WMD Compliance and Enforcement series No. 3. UNIDIR.
} 
request advisory opinions from the ICJ on any "legal question". ${ }^{44} \mathrm{An} I \mathrm{CJ}$ advisory opinion has never been requested.

\subsubsection{Routes to the ICJ outside treaty regimes}

Another possible way in which recourse to the ICJ regarding a compliance dispute can be achieved is where the States in question have accepted the jurisdiction of the Court independently of the WMD-treaty in question. ${ }^{45}$ Article 36(2) of the Statute of the ICJ provides for States to recognize the compulsory jurisdiction of the ICJ regarding any matter of international law. This would include compliance with a WMD-related treaty. However, jurisdiction will only operate if all parties to a specific dispute have accepted the jurisdiction of the Court. This limitation has proved to be an insurmountable obstacle to bringing WMDrelated disputes before the Court. For example, the Court declined jurisdiction when the Marshall Islands filed proceedings against the nine nuclear-armed States arguing that those States had breached their obligations to negotiate in good faith towards nuclear disarmament pursuant to article VI of the NPT and to customary international law. ${ }^{46}$ Of the nine, the United Kingdom was the only one that was a State Party of the NPT (and thus bound by art. VI of the treaty), and which had accepted the compulsory jurisdiction of the Court. $^{47}$

A judicial form of WMD-related treaty compliance dispute resolution is also possible through an advisory opinion from the ICJ. The two advisory opinions related to the use of nuclear weapons sought by the General Assembly and the World Health Organization in the mid1990s are examples of this form of litigation in the context of a weapons-related dispute. ${ }^{48}$

\subsection{COUNTERMEASURES}

In addition to treaty-based measures of enforcement, general international law continues to sit alongside those specific treaty processes and can be drawn on by States. An important enforcement measure provided by general international law is that of countermeasures. Countermeasures are actions taken by one State (or a group of States) in response to another State's violation of international law. An example comes from the Air Services Agreement Case, a dispute between the United States and France, in which it was confirmed that countermeasures are a right under international law. When France had-in the view of

\footnotetext{
${ }^{44}$ Art. XIV(5), CWC.

${ }^{45}$ Art. 36(2), Statute of the International Court of Justice.

${ }^{46}$ Obligations concerning Negotiations relating to Cessation of the Nuclear Arms Race and to Nuclear Disarmament (Marshall Islands v United Kingdom) (Judgment) [2016] ICJ Rep.

${ }^{47}$ At the time of the litigation, none of the other four acknowledged nuclear-weapon States were within the compulsory jurisdiction of the Court: China, France, the United States and the Russian Federation. India and Pakistan had also accepted the compulsory jurisdiction of the Court, but they were not States Parties of the NPT and thus did not have that treaty obligation. The case against the United Kingdom did not proceed because the Court found that there was no evidence of a justiciable dispute between the Parties at the time the proceedings were filed: Obligations Concerning Negotiations Relating to Cessation of the Nuclear Arms Race and to Nuclear Disarmament (Marshall Islands v United Kingdom) [2016] ICJ Rep 833.

${ }^{48}$ Legality of the Use by a State of Nuclear Weapons in Armed Conflict (Advisory Opinion) [1996] ICJ Rep 66; Legality of the Threat of Use of Nuclear Weapons (Advisory Opinion) [1996] ICJ Rep 226.
} 
the United States-breached its obligations under the Agreement, the United States responded by not permitting French planes to land. ${ }^{49}$ The Tribunal found that the United States had not acted wrongly in putting in place that countermeasure as recognized in article 50 of the Articles on State Responsibility. Countermeasures might be imposed unilaterally, or even multilaterally, but the relevant point is that countermeasures are an enforcement measure that sits outside any particular treaty regime, but remain (in the right circumstances) lawful under international law.

However, although they are undoubtedly recognized in international law, it is not absolutely clear that countermeasures are permissible in the context of an arms control treaty. Article 50 of the Articles on State Responsibility provides that certain obligations are not affected by countermeasures, including obligations for the protection of fundamental human rights (art. 50(1)(b)); obligations of a humanitarian character prohibiting reprisals (art. 50(1)(c)); and obligations under peremptory norms of general international law (art. 50(1)(d)). Disarmament obligations do not seem to fall into any of these categories. However, an argument could be made that provisions in relevant treaties prohibiting the use of particular weapons (for example, the use of chemical weapons) would fall within the humanitarian law prohibition on reprisals, or even peremptory norms of international law. If that is accepted, then countermeasures would not be a permissible enforcement action within those treaties. With the strengthening of humanitarian sensibilities within disarmament treaties, this argument gains greater credibility.

Finally, it should also be noted that while the imposition of countermeasures in a particular situation might be lawful as a matter of international law, they may be politically difficult if applied independently of the relevant treaty provisions and without independent, or credible, confirmation of non-compliance.

\subsection{WITHDRAWAL OR TERMINATION}

It is accepted in international law that unilateral withdrawal from a treaty, or the termination of the treaty, may be a lawful consequence of a wrongful act by another party. Withdrawal or termination of a treaty thus constitutes a lawful enforcement measure. Indeed, the recent withdrawal by the United States and subsequent collapse of the Intermediate-Range Nuclear Forces treaty-something discussed further by Podvig and Woolf in paper five in this series-provides one example of bilateral withdrawal and termination. ${ }^{50}$

In addition, many of the multilateral WMD-related treaties allow for withdrawal or termination in specific circumstances. ${ }^{51}$ Article 60 of the 1969 Vienna Convention on the Law

\footnotetext{
${ }^{49}$ See Case Concerning the Air Services Agreement of 27 March 1946, Award, 9 December 1978, 54 International Law Reports, p. 303.

50 Podvig, Pavel and Amy Woolf. 2019. "Monitoring, verification, and compliance resolution in U.S.-Russian arms control." WMD Compliance and Enforcement series No. 5. UNIDIR.

${ }^{51}$ Marauhn, Thilo, and Andreas Zimmermann. 2007. "Dispute Resolution, Compliance Control and Enforcement of International Arms Control Law". In Making Treaties Work: Human Rights, Environment and Arms Control, edited by Geir Ulfstein. pp. 243-72. https://doi.org/10.1017/CBO9780511494345.012. pp. 268-269.
} 
of Treaties provides two routes to suspend or terminate a treaty on the basis that another party has materially breached its provisions. The first is if that State is specially affected by the breach in question (art. 60(2)(b)). The second is if "the treaty is of such a character that a material breach of its provisions by one party radically changes the position of every party with respect to the further performance of its obligations under the treaty" (art. 60(2)(c)). Thus, it would be difficult, but not legally impossible, for States Parties to terminate a treaty on this basis as the threshold is so high.

However, while withdrawal from or termination of a treaty might be permissible from a legal point of view, it is probably politically difficult in multilateral treaties. That is because, like human rights or environmental treaties, WMD-related agreements are often better understood as being 'community interest agreements', as opposed to reciprocal agreements, such as a free trade agreement conferring benefits only on the Parties of the treaty in question. Seen in this way, States may be unwilling politically to terminate a multilateral WMD-treaty even if such a course of action is legally possible.

\subsection{OTHER POSSIBLE RESPONSES TO NON-COMPLIANCE}

Beyond these more typical responses to non-compliance, it is of note that States have other options that can be applied. For example, as noted above, States (and also non-State actors) can name and shame those in violation of a treaty. In the human rights sphere, this sometimes happens through litigation in domestic or international courts challenging a particular violation of human rights. Alternatively, it can be achieved through the provision of 'shadow reports' presented to an international body that challenge a State's account of its compliance with its obligations. Such 'naming and shaming' can be powerful, particularly in circumstances where States join treaties in part to foster an image as a 'responsible' State or a 'good international citizen'.

In addition, national or regional tools can be employed to respond to serious cases of noncompliance. Examples here include the use of regional or national sanctions targeted at States, individuals or private sector companies. Yet another alternative is the use of national courts to prosecute violations. Such measures are not without problems, but they do illustrate that there is a range of tools that can be applied in response to non-compliance, some of which are underexplored. 


\section{REFLECTIONS}

The previous sections explored various compliance and enforcement mechanisms available in international law generally, with specific reference to some WMD-related treaties. This section sets out a number of more general observations on the practice and theory of compliance and enforcement in WMD-related treaties. ${ }^{52}$

First, it is clear that when weapons-related treaty regimes are being designed, negotiators tend to draw on previous experiences in the area. For example, the CWC verification system was built on the design and experiences of the IAEA Safeguards system, with the CWC in turn providing the blueprint for the CTBT. ${ }^{53}$ Thus, although all the various regimes work independently and have quite separate institutional structures, often a full appreciation of any compliance and enforcement system requires an understanding of other WMD-treaty regimes. While this type of incremental development is understandable and even desirable, it can 'lock-in' negotiators to a particular mode of thinking. That is, existing processes and structures are the starting point in regime design, and designers are reluctant to engage in more innovative approaches using examples of practices in other areas.

This leads to a second observation. The incrementalism evident in designing compliance and enforcement mechanisms in the context of WMD-treaty regimes also often means that new thinking and debates about compliance theory can pass unnoticed. As explained in part two, traditional explanations for why States comply with their treaty obligations broadly fall into one of two camps: the rational actor or the normative. However, more nuanced thinking around why States comply is available. For example, some commentators suggest that binding human rights treaties do not lead to better human rights outcomes. ${ }^{54}$ Others argue that the more facilitative and cooperative compliance mechanisms evident in international environmental law secure better outcomes in terms of regime effectiveness. ${ }^{55}$

The point is that many of the blueprints applied in contemporary WMD regimes were devised at a time when different understandings prevailed about why States complied with their obligations. If understandings of the determinants of compliance and effectiveness of treaty regimes have changed, then those new understandings or theories ought to inform and assist in determining processes or procedures for ensuring/encouraging compliance.

\footnotetext{
52 Revill, James, John Borrie, Pavel Podvig and Jenn Hart. 2019. "Compliance and Enforcement: Lessons from across WMD Related-Regimes". WMD Compliance and Enforcement series No. 6. UNIDIR.

53 Tabassi, Lisa, Thilo Marauhn, and Andreas Zimmermann. 2007. "The Convention on the Prohibition of the Development, Production, Stockpiling and Use of Chemical Weapons and on Their Destruction (Chemical Weapons Convention)". In Making Treaties Work: Human Rights, Environment and Arms Control, edited by Geir Ulfstein. pp. 273-300. https://doi.org/10.1017/CBO9780511494345.013. pp. 298-299.

${ }^{54}$ Hathaway, Oona A. 2002. "Do Human Rights Treaties Make a Difference?". Yale Law Journal 111: 1935.

${ }^{55}$ Klabbers, Jan. 2008. "Compliance Procedures". In The Oxford Handbook of International Environmental Law, edited by Daniel Bodansky, Jutta Brunnée, and Ellen Hey. https://doi.org/10.1093/oxfordhb/9780199552153.013.0043.
} 
A third and related point, is that regimes outside of the weapons area are sometimes neglected in designing weapons-related regimes and important lessons and considerations could be garnered from them. For example, individuals have a much greater role to play in enforcing and ensuring compliance with various human rights treaties. Indeed, in some situations, individuals are able to challenge States directly in national or international courts or committees for alleged treaty violations. There is also a well-developed system in some human rights measures for non-State actors (often non-governmental human rights organizations) to provide 'shadow reports' to human rights committees considering a State's compliance with its treaty obligations. ${ }^{56}$

International environmental law also provides some innovative thinking. In particular, it is striking how many of the compliance and enforcement procedures developed in this field rest on normative theories of compliance-that is, they work on the basis that States want to comply with the obligations that they have undertaken. In this field, as with human rights, there are also instances where members of the public are able to bring concerns of noncompliance forward. For example, the Aarhus Convention establishes a Compliance Committee to which members of the public can submit a complaint about any State's noncompliance with that treaty. ${ }^{57}$ The Paris Agreement, building on earlier precedents, ${ }^{58}$ established a 'Compliance and Implementation Mechanism'. This is a standing body of independent experts (not representing States) established to consider certain aspects of compliance with the Paris Agreement. ${ }^{59}$

These ideas may not fit easily into a WMD-related regime. However, they might complement and strengthen existing compliance mechanisms. It could be timely to consider these developments, particularly as there is an increasing acknowledgement of the humanitarian aspects of arms control. This in turn suggests that a more inclusive approach might be appropriate in ensuring compliance, along with an appreciation of the growing array of tools and sources of information that can support WMD-related compliance mechanisms.

A fourth observation relates to the fact that across time there has been a definite shift to including ever more robust, detailed enforcement mechanisms in treaty regimes. This advance reflects a more general development in international law. However, as with all other areas of international law, enforcement or absolute compliance with treaty obligations will remain more of an ambition than a reality. It is striking that the continual-and tragicbreaches of human rights law do not lead scholars, diplomats or practitioners to publicly suggest that we should therefore abandon the human rights project. Even imperfect treaties

\footnotetext{
${ }^{56}$ See for example the discussion by Búrca, Gráinne de. 2017. "Human Rights Experimentalism". American Journal of International Law 111 (2): 277-316. https://doi.org/10.1017/ajil.2016.16.

57 Convention on Access to Information, Public Participation in Decision-making and Access to Justice in Environmental Matters [Aarhus Convention], adopted 25 June 1998, 2161 UNTS 447.

58 See Voigt, Christina. 2016. "The Compliance and Implementation Mechanism of the Paris Agreement". Review of European, Comparative and International Environmental Law 25 (2): 161-73. https://doi.org/10.1111/reel.12155.

${ }^{59}$ Art. 15, Aarhus Convention, and the 'Rulebook' which provided further detail on the operation and composition of the Mechanism; adopted by the States Parties: Decision 3/cma.1, Matters Relating to the Implementation of the Paris Agreement, FCCC/PA/CMA/2018/3/Add.1 (19 March 2019).
} 
provide a legal obligation on which to base arguments and establish an iterative process whereby expectations become clearer as to what is appropriate behaviour.

Fifth, it may be time to think more about external methods of dispute resolution. Indeed, it is notable how little recourse there has been to such methods in comparison to other areas of international law. Human rights and trade may not be appropriate comparators given the growth in specialized courts and tribunals in those areas. However, looking at the docket of the ICJ, it is conspicuous how relatively few attempts there have been to bring weaponsrelated disputes to that forum. Indeed, it is notable that, of the cases that have been attempted in recent decades, civil society has been the driver. Because of the very limited scope for civil society or individuals to play a formal role in the ICJ, it is unlikely that the Court will play a more impactful role anytime in the near future-not least because of the strong jurisdictional rules, the slow pace of litigation, and States being protective of their sovereignty.

However, there are other options, besides the ICJ. For example, during the negotiations of the Paris Agreement an International Tribunal to criminalize actions against the environment was proposed. The negotiating States did not accept that proposal. However, in the context of WMD, more attention could be paid to the role of the International Criminal Court, which is already in existence and already has jurisdiction over certain weapons. ${ }^{60}$

\footnotetext{
${ }^{60}$ See for example, Clark, Roger S. 2009. "Building on Article 8(2)(b)(XX) of the Rome Statute of the International Criminal Court: Weapons and Methods of Warfare". New Criminal Law Review 12 (3): 366-89. https://doi.org/10.1525/nclr.2009.12.3.366.
} 

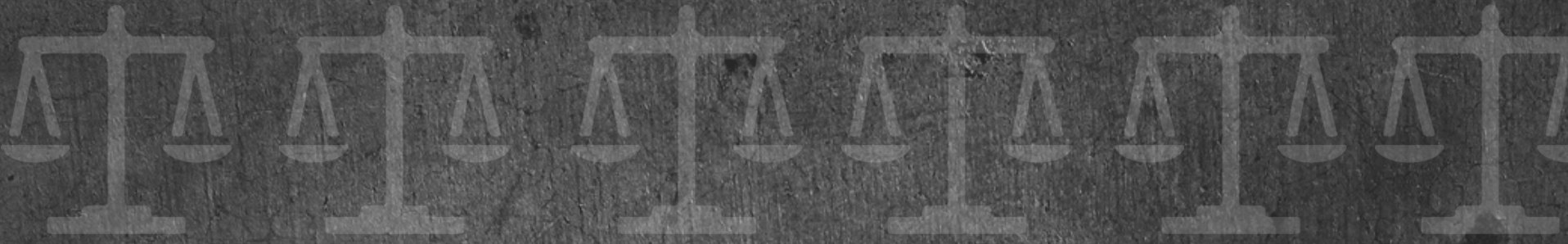

\section{WMD COMPLIANCE \& ENFORCEMENT SERIES}

\section{Compliance and Enforcement in} WMD-related Treaties

\section{IAEA Mechanisms to Ensure Compliance with NPT. Safeguards}

Compliance Management under the Chemical Weapons Convention

Compliance and Enforcement in the Biological Weapons Regime

Monitoring, verification, and compliance resolutión in U.S.-Russian arms control

Compliance and Enforcement: Lessons from across WMD-related regimes

\section{WWW.UNIDIR.ORG \\ @UNIDIR}

